Article

\title{
Proactive Divestiture and Business Innovation: R\&D Input and Output Performance
}

\author{
Kyungsuk Lee ${ }^{1}$ and Taewoo $\operatorname{Roh}^{2, *(1)}$ \\ 1 Graduate School of Arts and Sciences, Columbia University in the City of New York, 535 W 116th St \#109, \\ New York, NY 10027, USA; kl3069@columbia.edu \\ 2 Department of International Trade and Commerce, Soonchunhyang University, \\ Chungchungnam-do 31538, Korea \\ * Correspondence: troh@sch.ac.kr
}

Received: 18 March 2020; Accepted: 8 May 2020; Published: 9 May 2020

\begin{abstract}
We investigate the impact of proactive divestitures on innovative activities at a firm-level. Research concerning the relationship between proactive divestiture and innovation performance remains unexplored and requires a close investigation. Furthermore, we argue that proactive-divestiture is an essential means to achieve corporate sustainability by fostering innovation outcomes. To explore such a relationship, this study integrates research on knowledge-based view and organizational inertia and encompasses the model of financial distress. We hypothesize that proactive divestiture increases both the firm's R\&D intensity and the number of patents and propose that prior divestiture experiences and divested-unit size would moderate this relationship. Results indicate that proactive post-divestiture firms have increased in R\&D inputs but not significantly in output. We found mixed results for such a relationship as prior experiences increased, but interestingly, the relationship revealed to be more significant for both input and output as divested-unit size decreased. This study contributes to our understandings of how proactive divestiture can reinforce knowledge capacity, distant from a traditional resource-based view that mainly regarded divestiture as a mere responsive action vis-à-vis financial pressure.
\end{abstract}

Keywords: innovative activities; divestiture; prior experiences; proactiveness; relative size; business innovation performance

\section{Introduction}

Confronting with everchanging environments and industry landscapes, firms frequently assess their current strategies and portfolio management all the more. Such actions taken by firms are further demonstrated by the increasing trend of de-conglomeration for the past several years. The operating structure of numerous companies has become highly complexed and intervolved. However, as Berger and Ofek [1] stated, conglomerates generally perform around $13 \%$ to $15 \%$ discount as to more focused or single-segment firms within the same industry. Furthermore, shareholder activism affects firms to proactively manage capital assets and streamline product portfolios in order to stimulate firms' growth and shareholder values. Hence, the nature of corporate sustainability has been adjusted from merely increasing the size of the firm by means of mergers and acquisitions (M\&A) to vigorous structuring and maintaining the firm's operation efficiently by nurturing core values simultaneously.

Pursuant to Szekely and Strebel [2], sustainability-oriented innovation involves innovative activities that bolster performance in the three key elements of sustainable development: social, environmental, and economic. These improvements not only require technological adaptations but also demand firms' transformation in order to adjust to new market conditions and facilitate the improvement of competitive advantages. Innovation and corporate sustainability is positively 
related [3]. As a means to keep pace with technological innovation and foster firms' alacrity [4], divestiture is increasingly seen as a strategic option [5] taken by firms since it is apprehended as a necessary means to grow firm's core business and to exploit growth opportunities [6]. Specifically, divestiture is suitable for starting new business initiatives, reinforcing growth, and creating distinct novel firm value [7]. Thus, in recent years, divestiture transactions have expanded substantively as a global phenomenon [8] and thus illustrate that such phenomena cannot be overlooked as such situations can entail notable influence on not only firms or industry but also the entire economy. The portfolio-management approach further highlights the significance of divestiture as a legitimate management decision [9] for its broad applicability in business practice despite the firm's "scope, size, age, and industry background" [10].

Previous literature has focused mainly on motives of divestiture [11], determinants of divestiture transaction [12], and post-divestiture firm performance [5,9]. These findings assume that the divestiture can be treated as a tool that is needed for firms to correct strategic mistakes in order to pursue better and stable cash flows to operate. For example, Hayward and Shimizhu [13] argued that if any firm wishes to engage in divestiture, most transactions occur in reaction to financial pressure. Similarly, Dranikoff et al. [12] found that when firms decide to divest in response to some pressure, they often do it reactively.

Nevertheless, most attempts have ignored that divestiture can be executed without financial pressure and thus cannot be solely considered as a responsive action by firms [14]. Darnall and Edwards [15] further highlighted the importance of divestiture as a proactive strategy, which is a necessity to sustain a firm's profitability and growth over the long term. Brunetta and Peruffo [16] also asserted that divestiture can improve a firm's innovation process as a proactive decision that is practical for firms to engage in new business tasks. However, most studies relevant to the divestiture realm builds on the traditional viewpoint that firms participate in response to financial pressure. To our knowledge, linking proactive divestiture and a firm's innovation performance is quite qualitative in nature, and thus, empirical studies observing such a relationship on corporate sustainability are very limited. Extant of contributing to the research stream of M\&A and corporate sustainability literature, this paper aims to demonstrate insight on how firms could engage in proactive divestiture for strategic reasons in accordance with increasing innovation performance, which is crucial for sustainable business operations.

More specifically, we examine the relationship between proactive divestiture and innovation performance via research and development $(R \& D)$ intensity and patents as an innovative outcome. Furthermore, we examine how the size of the business unit relative to the firm and prior divestiture experiences could influence on firm's innovative performance within firms who engaged in proactive divestiture. Through this research, we expect to explore that proactive divestiture could be an efficient means to intensify knowledge-building capability to create new value for parent firms [17]. In this line, the purpose of our study is to enlarge the scope of divestiture as a proactive transaction and to provide us with a more thorough comprehension of innovation relatedness to corporate sustainability.

This article is thus structured as follows. First, we review the literature on divestiture based on the traditional view of reactive action and alternative view as a proactive action, with a focus on two theories (resource-based view and knowledge-based view) that could explain proactive divestiture. Second, we develop a theoretical model and hypotheses that explore the relationship between post-divestiture and innovation performance based on the alternative perspective on divestiture as a proactive action. To do so, we perform an empirical test on R\&D intensity, patents, size of the business unit, and prior divestiture experiences to show how innovation performance is affected by divestiture. Finally, in the last section, we illustrate results and discussions. 


\section{Literature Review and Hypothesis Development}

\subsection{Divestiture and Business Innovation}

Traditionally, divestiture has been more focused on being a financial mechanism or tool in order to improve the firm's efficiencies [7]. Therefore, firms divest business to reduce debt and reconfigure their portfolio of assets [18]. Markides and Singh [18] further stated that by understanding divestiture as only a means of previous retreating errors that the firm has made would diminish divestiture's true meaning as a strategically purposeful action. These were considered reactive action by the firms since divestiture was the means to correct the error to improve the efficiency of the firm and thus the re-stabilize stream of cash flow. Dranikoff et al. [12], in their study of 50 of the largest divestiture transactions, found that between 1998 and 2002, over three-quarters of the firms engaged in reactive divestiture. The majority of them were executed after long delays when such transactions turned out to be inevitable for firms to resolve in-house problems.

The reactive response of firms engaging in divestiture could be because of reluctance since a business unit may generate stable cash flow and thus bring market advantages to the current firm [12]. Therefore, this belief within the firms increases the likelihood that those firms perform divestiture at the last moment when financial pressure becomes obvious and hinders the overall performance of the company. Financial pressure encourages firms to promote efficiency-enhancing activities in order to retrieve profit from decreasing firm performance [19]. Furthermore, Whitaker [20] argued that "financially distressed firms frequently undertake major asset divestitures to raise cash to satisfy creditor demands or more efficiently structure the operations of the firm." These notions imply that firms that divest their part of the business are reactive responses in order to resolve financial problems rather than executing divestiture as a proactive action.

However, firms being reactive towards divestiture could result in costs that could be inflicted on both the entire firm and the business itself [12]. Specifically, for the post-divestiture companies, it can discourage firms from wanting to generate new and high-growth businesses. Therefore, an alternative view of divestiture was introduced to explain the process that firms engage, regardless of financial pressure. Proactive divestiture is defined as "Divestiture initiated in advance, in more positive performance context", while reactive divestiture is "The one conducted in response to some pressure such as low profitability. The key standard that distinguishes reactive and proactive divestitures is whether the firm initiated divestiture under financial pressure or not." [21]. Thus, firms engaging in divestiture to reconfigure and reconstruct their existing assets or resources to promote further growth of the firm have to be considered as engaging in proactive action since its purpose is to strengthen its core business and exploit opportunities in order to gain sustainable competitive advantage, regardless of financial pressure. Business sectors that are divested from parent firms are considered to be "unimportant, unsuccessful, and reluctant" compared to acquiring firms [22]. Therefore, divestiture promotes the growth of the firm and the re-creation of firm-value for the survival of the parent company [16]. A more recent survey highlights that in business practice, divestiture is a significant activity in order to refocus and grow the firm's core business [12]. Studies above imply that divestiture can be viewed as proactive action in order to strengthen the firm's core business and exploit opportunities to gain competitive advantage rather than fixing past mistakes in order to re-gain stable cash flow, as the majority of traditional viewed. This is because divestiture, through reconfiguration process, promotes the firm's resources to be valuable, rare, and non-imitable since the process of divestiture improves the efficiency of the firm to be more focused on its unique competency.

Reconfiguration of resources is not the only advantage that proactive divestiture could improve a firm's sustainable competitive advantage over rivals. The knowledge-based view also suggests that accrual of knowledge can aid firms in further growth since such a process makes firms identify and exploit new opportunities. A firm could be considered a huge depository of knowledge [23]. Thus, accumulative knowledge and learning could be considered as a basis for sustainable competitive advantage [24]. In a similar fashion, divestiture has been mentioned in international literature as an 
activity that can make firms finance more internal knowledge or R\&D by further investigating and seeking the latest information outside any capabilities that the firm already has [4] and thus achieve corporate sustainability. Furthermore, firm-level theories regarding technological change argue that the firm's innovative output is affected by the accumulation of knowledge $[25,26]$. Divestiture and innovation performance proved to be in a positive relationship among corporate control literature since divestiture can make firms re-allocate assets and resources, focusing on R\&D activities that, in turn, improve the process of innovation and thus result in the firm's competitive advantage [27].

Combining the two theories, we conclude that established firms can promote innovation performance via the reconfiguring process of their resources and knowledge. Indeed, innovation is dedicated to active and creative courses that support firms to restructure internal and external resources. Put it differently, the actions that are taken by firms to reconstruct their portfolio of an asset can be regarded as a means to recognize unique, innovative opportunities [28]. Divestiture is considered to be the most practical strategies to promote corporate restructuring programs to refocus on their core competencies or business assets, which makes it more possible for firms to observe new opportunities and thus push forward innovative activities. In this viewpoint, the proactive perspective of divestiture highlights not only the common positive effect of divestiture on innovation but also the contribution to corporate sustainability since innovation is increasing its awareness as a key element towards sustainability [29]. As firms get more prominent and hold more separate businesses, it is difficult for managers to take control effectively. This results in lessening the value of the firm and thus seeks to reconsolidate its assets toward core competency by divesting unrelated business sectors [30]. Furthermore, divestiture results in more than a financial asset that can be utilized to promote developing new products and activities [27]. In short, the alternative viewpoint on divestiture implies that divestiture increases the depth of innovation levels. Thus, as the studies above have suggested, increasing the slack resources to be invested in R\&D and redesigning of resources in order to explore and exploit new opportunities, accumulation of knowledge, and innovative capabilities will direct substantial resources headed for enhancing any knowledge and technological capacity that the firm already possesses.

Meanwhile, within firms who perform proactive divestiture, we expect that there could be different results regarding the number of prior divestiture experiences and relative size of the divesting unit. Prior divestiture experiences may influence innovative activities since routines and recognized arrays of beliefs and behaviors can result in organizational inertia [31] that promotes firms to carry out the way things are. These institutionalized mechanisms may provide a lack of experiences regarding divestiture and, in return, an insufficient commitment of innovative activities (both input and output) by the firms compared to those who have past involvements on such transactions. Furthermore, business unit size is crucial for firms when preparing divestment judgments [32]. This may be due to the intensive commitment that has been put to the business unit involving the allocation of capital, such as R\&D financing [33] or labor force. Therefore, the size of the divesting unit is also an important variable that is profound in organizational decision-making. Based on a review of the existing studies, we anticipate that two variables, prior divestiture experiences and size of the business unit, would moderate the effects on the relationship between proactive divestiture and innovation performance and is needed for closer attention to delivering better comprehension of the specific features of the proactive divestiture phenomenon according to sustainable business principles.

\subsection{Proactive Divestiture and RED Inputs}

Technological know-how inside the company and in-house R\&D are considered to be vital factors of the innovation process [34]. Technological know-how and R\&D promote firms to generate, foster, and convert new knowledge to develop new products or processes [35]. Thus, improvements in technological know-how amplify the launching of new investments and the likelihood of creating internal innovations rather than earning from outside sources [36]. This process of an innovation effort is needed for firms since the optimum utilization of resources and knowledge results in the profitability 
of the firm as reasoned that firms could be reflected as "huge depositories of knowledge" [23]. Moreover, the accumulation of knowledge can benefit firms by promoting further growth as such procedure creates opportunities for firms to recognize and to discover novel opportunities [37]. Therefore, not only what firms acquire and hold is important, but ways to utilize those resources and assets in order to develop new products and processes are also important. If asset divestiture could be entrenched in the broader scope of corporate reformation efforts, it can promote the development of innovation [38]. Divestiture is considered to be one of the most useful perspectives with regards to promoting reconfiguration strategies leading to innovative input since it can encourage firms to finance more on R\&D activities [4]. Thus, reducing the level of diversification via corporate divestiture increases their level of R\&D intensity [27]. Furthermore, acquisition activity in order to enlarge the firm's size has a negative impact on R\&D inputs [39]. These points may lead to explain why reconfiguring resources is vital for innovation as such processes promote firms to utilize resources in a different and new way for firms to engage in innovative activities [40]. The literature above leads us to argue that divestiture could further push forward innovative input activity by firms, which could be extended to be argued through proactive divestiture.

Hypothesis 1 (H1): Proactive divestiture has a positive relationship with innovative activities, specifically $R \mathcal{E D}$ input (RED intensity).

\subsection{Proactive Divestiture and RED Outputs}

Firms engaging in an acquisition may interrupt internal knowledge development or R\&D activities [37]. This is because, despite how such a process is financed, managerial distribution of residual resources might turn out to be constrained, instigating managers to omit other investment chances such as R\&D opportunities [39]. Similarly, acquisition processes and innovation have substitution effects as managerial devotion is further dedicated to size building rather than allocating resources that result in the development of unique products and technological procedures in line with marketplace opportunities [41]. Moreover, R\&D resources have to be treated efficiently in order for new products or process ideas to be established into patentable products or processes [37,39]. However, acquisition results in a lack of managerial commitment for such development. However, divestiture opposed to acquisition promotes the growth of the firm and the re-creation of firm-value [7] through the reconfiguration of assets and resources, resulting in managerial commitment being more focused on internal knowledge or R\&D developments [42]. While firm-level theories argue that the firm's innovative outcome is influenced by the accrual of knowledge [25,26], as mentioned earlier, we argue that as divestiture provides opportunities to increase the innovative input activities, it can also have a positive effect towards the outcome of the innovation process. The aforementioned literature leads us to argue that divestiture could further push forward innovative output activity by firms, which could be extended to be argued through proactive divestiture.

Hypothesis 2 (H2): Proactive divestiture has a positive relationship with innovative activities, specifically $R \mathcal{E D}$ output (number of patents).

\subsection{Moderation of Prior Divestiture Experiences}

When firms make an organizational decision, prior practices and regular routines perform a vital role [43]. Prior experiences on divestiture may assist firms in engaging in divestiture by instituting routines [44]. On the contrary, with firms that have little or no divestiture experiences may view divestiture as an irrational decision since it violates the past routines of the firm [45]. Particularly, a parent firm's prior divestiture experiences have a substantial effect on its judgment on whether to divest or not. This is because, as parent firms have sufficient divestiture experiences, the managers are able to well apprehend not only the advantage and disadvantage of a divestiture but also the organizational procedures concerned with implementation [21]. In a similar context, firms engage in 
internal and external knowledge acquisition activities since the marginal return of one action improves other activities simultaneously [46]. Thus, internal know-how could improve marginal return to external know-how as an accumulation process goes on. This concept can also be explained by absorptive capacity, which is defined as an ability to assimilate and recognize the new valuable information in order to implement on the firm's operation based on prior related knowledge that the firm already has [47]. As the firm accumulates absorptive capacity from one point to another, it is more efficient for firms to acquire and assimilate as the event occurs. Therefore, better understanding permits firms to evaluate and implement technologies that would further enhance the new technological development. By combining the aforementioned studies, they indicate that firms may accrue technological know-how or invest in R\&D as a number of divestitures occur [48]. As mentioned above in the two hypotheses, divestiture allows and promotes innovative activities on both input and output. Accumulation of divestiture thus allows firms to stimulate internal know-how as the firm's overall R\&D capacity may increase because of internal knowledge acquisition activities that could improve the firm's overall prospective knowledge-development. Furthermore, as divestiture and innovation performance is shown to have a positive relationship [27], we argue that this relationship would further improve as firms inhabit more divestiture experiences.

Hypothesis 3 (H3): The positive relationship between proactive divestiture and innovation performance (both input and output) becomes stronger as a number of prior divestiture experiences increase.

\subsection{Relative Firm Size of Business Unit}

Within numerous studies at firm-level, the size of the business unit has been understood as a vital factor [49]. This is because the size of the unit may affect strategy-structure linkage [50], involvement in the firm's decisions [32], and firm performance [51]. These influences occur since the business unit itself could be connected via psychological and financial bonds with parent firms [33]. Thus, complex affiliation amongst numerous divisions and individuals makes it more demanding to detach business units from firms as it generates problems among the remaining units.

Therefore, these bonds cause firms to be hesitant to divest part of their business unit. Particularly, divesting a large unit could turn out to be more difficult since the procedure itself is potentially more complicated and less routinized compared to divesting a small unit. In very few instances do large corporations systematically divested themselves of a major division as part of a planned strategy [52]. Moreover, companies would divest units which are considerably smaller in size [53], as large units have a higher possibility of a close relationship with firm's core business, high investment (e.g., R\&D funds), and managerial effort, and their divestment would result in discontinuity of critical supply relationships and difficulty of replacement $[33,44]$. Thus, from a firm perspective, it would be more appealing to divest smaller units since resource commitment and the effects on the remaining units would be smaller. Thus, we anticipate the relative size of the divesting unit to moderate the relationship between proactive divestiture and innovation performance.

Hypothesis 4 (H4): The positive relationship between proactive divestiture and innovation performance (both input and output) is negatively moderated by the relative size of the divesting unit.

\section{Methods}

\subsection{Sample}

Our sample was derived from US-based and publicly held firms that have engaged in divestiture between the years of 2006 to 2011. Firms are more likely to engage in divestiture in order to sell their less-related businesses as a strategic goal in an economic downturn [54]. As the main reason for a high level of divestitures between the years of 2008 and 2009 was the economic downturn [8], 
we proposed a time window of \pm 2 years of the economic downturn in order to comprehend proactive divestiture better.

This study constrained the sample to US-based public firms in order to make sure that we could retrieve financial information on divested units and its parent firms and circumvent any possible perplexing issues (for instance, different country risks and legal or regulatory matters regarding divestiture). Moreover, distant from previous studies that limited the sample to units that were formerly acquired, Brauer [49] measured entire division divestitures comprising business units that the parent firm initially started. Furthermore, firms' performance less than USD 50 million in terms of revenue, were removed from this study to eliminate any small firms effects that might occur.

Particularly, high-tech firms were chosen in this study since R\&D and innovation are considered the vital source for companies' competitiveness and survival; as such, these industries are portrayed by short product life cycles and high uncertainty that leads to stiff competition. More specifically, in an exceptionally competitive situation (e.g., rapid pace of technological change), such as the high tech industry, the survival and sustainable advantage of high-tech firms reside in their R\&D capacity [55]. Thus, it seems evident that high-tech firms require R\&D enhancement and innovative output to accomplish these objectives [56]. Moreover, as numerous reports demonstrate that divestiture was vigorous in high-tech industries, it seemed more appropriate to restrict the sample based on high-tech firms.

In previous high-tech divestiture studies [57], firms in SIC 28 (biotechnology and manufacturing), SIC 35 (industrial and commercial machinery and computer equipment), SIC 36 (electronic and other electrical equipment and components, except computer equipment manufacturing), SIC 38 (measuring, analyzing, and controlling instruments; photographic, medical and optical goods; watches and clocks manufacturing), SIC 737 (computer programming, data processing, and other computer-related services) have been commonly observed.

Involving the sample selection, we gathered entire divestiture transactions that had been completed between the years of 2006 through to 2011. US-based publicly held parent firms that possessed operating revenue exceeding USD 50 million and industries in SIC 28, 35, 36, 38, and 737 were found from the Bureau van Dijk Zephyr database, resulting in a total of 392 deals. Subsequently, we collected financial information, including R\&D expenditure and total revenues from COMPUSTAT data. In this process, we removed 140 deals because of a lack of information. Then, to calculate several patents, data were collected from the USPTO database. A final assessment of eliminating samples with omitted data yielded a valid sample size of 149 transactions with 117 equivalent parent firms.

\subsection{Measurement}

\subsubsection{Dependent Variables}

R\&D Intensity. R\&D intensity was calculated by dividing R\&D expenditure by total revenues (i.e., the parent firm's). This measure is consistent with the measure that Brauer [27] applied to calculate R\&D intensity. Both of R\&D expenditure and total revenues were found on "Wharton Research Data Services" using COMPUSTAT data.

Number of Patents. In the case of innovation output, it is well known that a patent represents the amount of applicability throughout scientific and technological fields. It is identified as a vital means to have an important role in demonstrating innovative performance [35]. Furthermore, firms engaging in acquisition have a negative relationship with innovative output [39]. This notion provides that divestiture could have a positive influence on a firm's innovation outcome. Thus, examining innovative output by several patents seemed necessary. The patent indicates the magnitude as an innovation output created by the firm's R\&D input, which is developed from the current states of know-how [58]. Thus, the outcome of the innovative activity can be measured by several patents that represents newly exploited inventions. Several of the patents were collected from the US Patent 
and Trademark Office database. They were calculated as the average number of annual patents after divestiture was completed for three years.

\subsubsection{Explanatory Variables}

Proactive Divestiture. We reaffirm that proactive divestiture is defined as "divestiture initiated in advance in more positive performance context", while reactive divestiture is "the one conducted in response to some pressure, such as low profitability" [21]. As we discriminate two constructs through financial pressure, it is vital to understand whether firms were under any financial pressure and, if they were, the amount of pressure. Financial distress is defined as "the situation in which the firm's cash flow is insufficient to cover its current obligation" in finance research [20]. Such distress drives firms to engage in efficiency-enhancing activities in order to retrieve profit from poor firm performance [19]. The explanation of financial distress can be interpreted as financial pressure in strategic management studies with regards to the feeling of reactive divestiture of vendors. Thus, we also implement the equal measure that the majority of finance researchers have applied to compute financial distress as the difference cash flow between the current maturities of long-term debt. The positive result denotes how much the firm was distant from financial distress, which illustrates the level of proactive-ness. On the other hand, negative results show how much the firm was under financial pressure, which indicates the level of reactiveness.

Relative Size. Relative unit size to a parent firm was computed by dividing the transaction value by its parent firm's total asset [33].

Prior Divestiture Experiences. The prior divestiture experiences were counted until the year of divestiture was competed by parent firms. As prior experiences were frequently calculated as the 3-year window [44,45], we have also used this measure to calculate prior experiences.

\subsubsection{Control Variables}

We have included several control variables in order to exclude any possibility that might alter our explanations in the current study. The following variables have been cautiously selected by reviewing prior researches on divestiture, $\mathrm{M} \& \mathrm{~A}$, and corporate governance, which were recognized as relevant. The seven variables are as follows.

Firm Size. Firm size has been recognized as a prominent feature that increases divestiture transactions [6]. Firm size was calculated by taking the logarithms of the number of employees [59].

Firm Age. The firm's age is known to have a substantial effect on generating organizational inertia [13], which may influence the divestiture process. Thus, we have included in the control variable. Firm age was measured by deducting the year when the firm was established from the year when divestiture occurred.

Deal Duration. The deal duration for divestiture could arouse riskiness of the transaction and thus influence the responsiveness of the selling company [60]. The majority of past studies on divestiture did not consider the possibility of divestiture and the duration of its process as vital aspects. However, as this study is focused on the timing of the divestiture, we have included deal duration in the control variable.

High-tech industries. The selling firms or vendors in this study all reside in high-tech industries. However, as sample firms consist of 5 separate SIC code industries, these codes may have different influences on the result of this study $[57,61]$. Therefore, the five industries were treated as dummy variables, which were regarded as two digits (SIC 28, SIC 35, SIC 36, SIC 38, SIC 73).

Divested Year. Each divested year (2006-2010) was included as a dummy variable in order to control for overall longitudinal tendencies and undetected heterogeneity $[62,63]$. 
Deal Value. As the divestiture phenomenon can be considered the opposite of M\&A, we also have included deal value as a control variable since the size of the transaction is typically treated as a control variable in empirical observations within M\&A studies for performance outcome [38].

\subsubsection{Estimation Analysis}

All variables except divested years and SIC industry were continuous, and some variables such as relative size, number of divestiture experience, and proactive divestiture were centered on testing the moderating effect. We then analyzed the sample using ordinary least squared (OLS) regression analysis when the dependent variable is R\&D intensity as an innovation input. Meanwhile, the number of patents was also used as the dependent variable to measure the firm's innovation output. Among the most prevalent methods to measure the number of patents as a proxy, Poisson and negative binominal regression, we adopted negative binomial regression for the analysis. There are several reasons. First, negative binomial regression is suitable for estimating models of counts (occurrences) of an event [64] and when overdispersion exists [65]. Second, the count model, here negative binomial regression, is well-suited for the discreteness of the number of patents [66]. Lastly, negative binomial regression is an expansion of Poisson regression where $Y_{j}$ is a consequence of an aggregate Poisson distribution when it follows a mixed distribution of gamma [67]. Consequently, as the number of patents is highly likely to follow Poisson distribution, we adopted such a method for our analysis. In this paper, the probability that the number of patents occurred $Y_{j}$ times are as follows:

$$
\operatorname{Prob}(\mathrm{Y}=\mathrm{yj})=\mathrm{e}^{-\lambda_{\mathrm{j}}} \lambda_{j}^{Y_{j}} / Y_{j} !
$$

where $\lambda_{\mathrm{j}}=\exp \left(\sum B_{i} X_{i j}\right) \exp \left(u_{j}\right)$ and $\mathrm{u}_{\mathrm{j}} \sim$ Gamma, $1 / \alpha$ for observed counts of patent $\mathrm{Y}_{\mathrm{j}}$ with covariates $X_{i}$ produced by firm .

\section{Results}

In Tables 1-3, descriptive statistics and correlation results are displayed. In Table 2, most coefficients of correlation are significant $(p<0.05)$ using R\&D intensity as a dependent variable. In Table 3 , the similar significant patterns described. Firm size, number of divestiture experience, and proactive divestiture are positively significant and correlated with dependent variables. Furthermore, we check out the multicollinearity with VIF (variance inflation factor) and it turns out that the mean VIF was 2.25, ranging from 1.49 to 3.12. Since the cutoffs of VIF are less than 10, the model is less likely to have a multicollinearity problem [68].

Table 1. Descriptive statistics.

\begin{tabular}{ccccccccc}
\hline Variables & Obs. & Mean & SD & Median & Min. & Max. & Skewness & Kurtosis \\
\hline RDI & 149 & 302.2 & 1103.1 & 5.1 & 0 & 8578 & 5.3 & 33 \\
NP & 149 & 67.2 & 238.2 & 1.2 & 0 & 1723.3 & 5.4 & 33.1 \\
FS & 149 & 1.3 & 2 & 1.4 & -6.9 & 5.9 & -0.4 & 3.6 \\
DD & 149 & 53.6 & 96.4 & 34.5 & 0 & 944 & 6 & 51.7 \\
FA & 149 & 35.9 & 27.4 & 26 & 1 & 127 & 1.1 & 3.6 \\
RS & 149 & 0.4 & 1.4 & 0.1 & 0 & 16.5 & 11 & 130.6 \\
DV & 149 & 4.1 & 1.8 & 4.1 & -1.8 & 9.1 & -0.1 & 3.5 \\
NDE & 149 & 4.8 & 7.2 & 2 & 0 & 49 & 2.7 & 12.7 \\
PD & 149 & 1145.4 & 4025.5 & 74 & -1861.6 & 25,460 & 4.7 & 25.2 \\
\hline
\end{tabular}

Notes: ${ }^{a}$ logarithm, RDI $=\mathrm{R} \& D$ intensity, $\mathrm{NP}=$ number of patents, $\mathrm{FS}=$ firm size, $\mathrm{DD}=$ deal duration, $\mathrm{FA}=$ firm age, $\mathrm{RS}=$ relative size, $\mathrm{DV}=$ deal value, $\mathrm{NDE}=$ number of divestiture experience, $\mathrm{PD}=$ proactive divestiture. 
Table 2. Correlation matrix for R\&D intensity $(n=149)$.

\begin{tabular}{|c|c|c|c|c|c|c|c|c|c|}
\hline & Variables & 1 & 2 & 3 & 4 & 5 & 6 & 7 & 8 \\
\hline 1. & R\&D Intensity & 1 & & & & & & & \\
\hline 2. & Firm size & $0.36^{*}$ & 1 & & & & & & \\
\hline 3. & Deal duration & -0.03 & 0.09 & 1 & & & & & \\
\hline 4. & Firm age & 0.11 & $0.27^{*}$ & 0.00 & 1 & & & & \\
\hline 5. & Relative size & -0.05 & -0.14 & 0.05 & -0.08 & 1 & & & \\
\hline 6. & Deal value & 0.14 & $0.45^{*}$ & $0.22^{*}$ & 0.14 & $0.21^{*}$ & 1 & & \\
\hline 7. & Number of divestiture experience & $0.41^{*}$ & $0.51^{*}$ & 0.15 & 0.07 & 0.15 & $0.34^{*}$ & 1 & \\
\hline 8. & Proactive divestiture & $0.51^{*}$ & $0.47^{*}$ & $0.27^{*}$ & 0.02 & -0.07 & $0.25^{*}$ & $0.54^{*}$ & 1 \\
\hline
\end{tabular}

Table 3. Correlation matrix for the number of patents $(n=149)$.

\begin{tabular}{|c|c|c|c|c|c|c|c|c|c|}
\hline & Variables & 1 & 2 & 3 & 4 & 5 & 6 & 7 & 8 \\
\hline 1. & Number of patents & 1 & & & & & & & \\
\hline 2. & Firm size & $0.37^{*}$ & 1 & & & & & & \\
\hline 3. & Deal duration & -0.03 & 0.09 & 1 & & & & & \\
\hline 4. & Firm age & 0.05 & $0.27^{*}$ & -0.00 & 1 & & & & \\
\hline 5. & Relative size & -0.05 & -0.14 & 0.05 & -0.08 & 1 & & & \\
\hline 6. & Deal value & 0.13 & $0.45^{*}$ & $0.22^{*}$ & 0.14 & $0.21^{*}$ & 1 & & \\
\hline 7. & Number of divestiture experience & $0.40^{*}$ & $0.51^{*}$ & 0.15 & 0.07 & 0.15 & $0.34^{*}$ & 1 & \\
\hline 8. & Proactive divestiture & $0.37^{*}$ & $0.47^{*}$ & $0.27^{*}$ & 0.02 & -0.07 & $0.25^{*}$ & $0.54^{*}$ & 1 \\
\hline
\end{tabular}

Note: ${ }^{*} p<0.05$.

This study has used both ordinary least squares and negative binomial regression to test the hypotheses. A total of eight models was investigated in Table 4. Model 1 and 2 are comprised of R\&D intensity, and several patents regressed on the control variables only. Model 3 includes the moderating effects model for R\&D intensity, comprising the addition of an interaction term of proactive divestiture and the number of divestiture experiences. Model 4 contains the moderating effect model for the number of patents, also comprising the addition of the interaction term of proactive divestiture and number of divestiture experiences. Model 5 includes the moderating effect model for the number of patents, comprising the addition of the interaction term of proactive divestiture and relative size. Model 6 has the last moderating effect model for R\&D intensity, also comprising the addition of an interaction term of proactive divestiture and relative size. Models 7 and 8, the full models, regressed on all the explanatory variables.

Table 4. Results of regression models using R\&D intensity and number of patents as dependent variables.

\begin{tabular}{ccccccccc}
\hline $\begin{array}{c}\text { Variables } \\
\text { (Dependent Variable) }\end{array}$ & $\begin{array}{c}\text { Model 1 } \\
\text { (RDI) }\end{array}$ & $\begin{array}{c}\text { Model 2 } \\
\text { (NP) }\end{array}$ & $\begin{array}{c}\text { Model 3 } \\
\text { (RDI) }\end{array}$ & $\begin{array}{c}\text { Model 4 } \\
\text { (NP) }\end{array}$ & $\begin{array}{c}\text { Model 5 } \\
\text { (RDI) }\end{array}$ & $\begin{array}{c}\text { Model 6 } \\
\text { (NP) }\end{array}$ & $\begin{array}{c}\text { Model 7 } \\
\text { (RDI) }\end{array}$ & $\begin{array}{c}\text { Model 8 } \\
\text { (NP) }\end{array}$ \\
\hline Industry (SIC 2digit $=28)$ & 0.014 & -0.000 & 0.003 & -0.000 & -0.015 & -0.000 & -0.044 & -0.000 \\
& $(0.151)$ & $(-0.391)$ & $(0.035)$ & $(-0.377)$ & $(-0.177)$ & $(-0.480)$ & $(-0.586)$ & $(-0.475)$ \\
Industry (SIC 2digit $=35)$ & 0.016 & 0.001 & -0.006 & 0.001 & 0.031 & 0.001 & -0.002 & 0.001 \\
& $(0.174)$ & $(1.068)$ & $(-0.068)$ & $(0.989)$ & $(0.356)$ & $(0.896)$ & $(-0.021)$ & $(0.861)$ \\
Industry (SIC 2digit $=36)$ & -0.015 & $0.003^{* * *}$ & -0.006 & $0.003^{* * *}$ & -0.006 & $0.003^{* * *}$ & 0.012 & $0.003^{* * *}$ \\
& $(-0.151)$ & $(3.730)$ & $(-0.061)$ & $(3.563)$ & $(-0.067)$ & $(3.509)$ & $(0.157)$ & $(3.423)$ \\
Industry (SIC 2digit $=38)$ & -0.021 & -0.001 & -0.023 & -0.001 & -0.001 & -0.001 & 0.003 & -0.001 \\
& $(-0.242)$ & $(-1.515)$ & $(-0.277)$ & $(-1.481)$ & $(-0.007)$ & $(-1.397)$ & $(0.049)$ & $(-1.374)$ \\
Divested year 2006 & 0.044 & 0.001 & 0.015 & 0.001 & 0.079 & 0.001 & 0.042 & 0.001 \\
& $(0.342)$ & $(0.486)$ & $(0.119)$ & $(0.651)$ & $(0.663)$ & $(0.647)$ & $(0.406)$ & $(0.790)$ \\
Divested year 2007 & 0.002 & 0.000 & -0.057 & 0.001 & 0.021 & 0.000 & -0.071 & 0.001 \\
& $(0.018)$ & $(0.250)$ & $(-0.444)$ & $(0.655)$ & $(0.175)$ & $(0.232)$ & $(-0.663)$ & $(0.652)$ \\
Divested year 2008 & 0.010 & 0.002 & -0.037 & $0.002^{+}$ & 0.052 & 0.001 & -0.011 & $0.002^{+}$ \\
& $(0.079)$ & $(1.584)$ & $(-0.290)$ & $(1.810)$ & $(0.435)$ & $(1.516)$ & $(-0.102)$ & $(1.737)$ \\
\hline
\end{tabular}


Table 4. Cont.

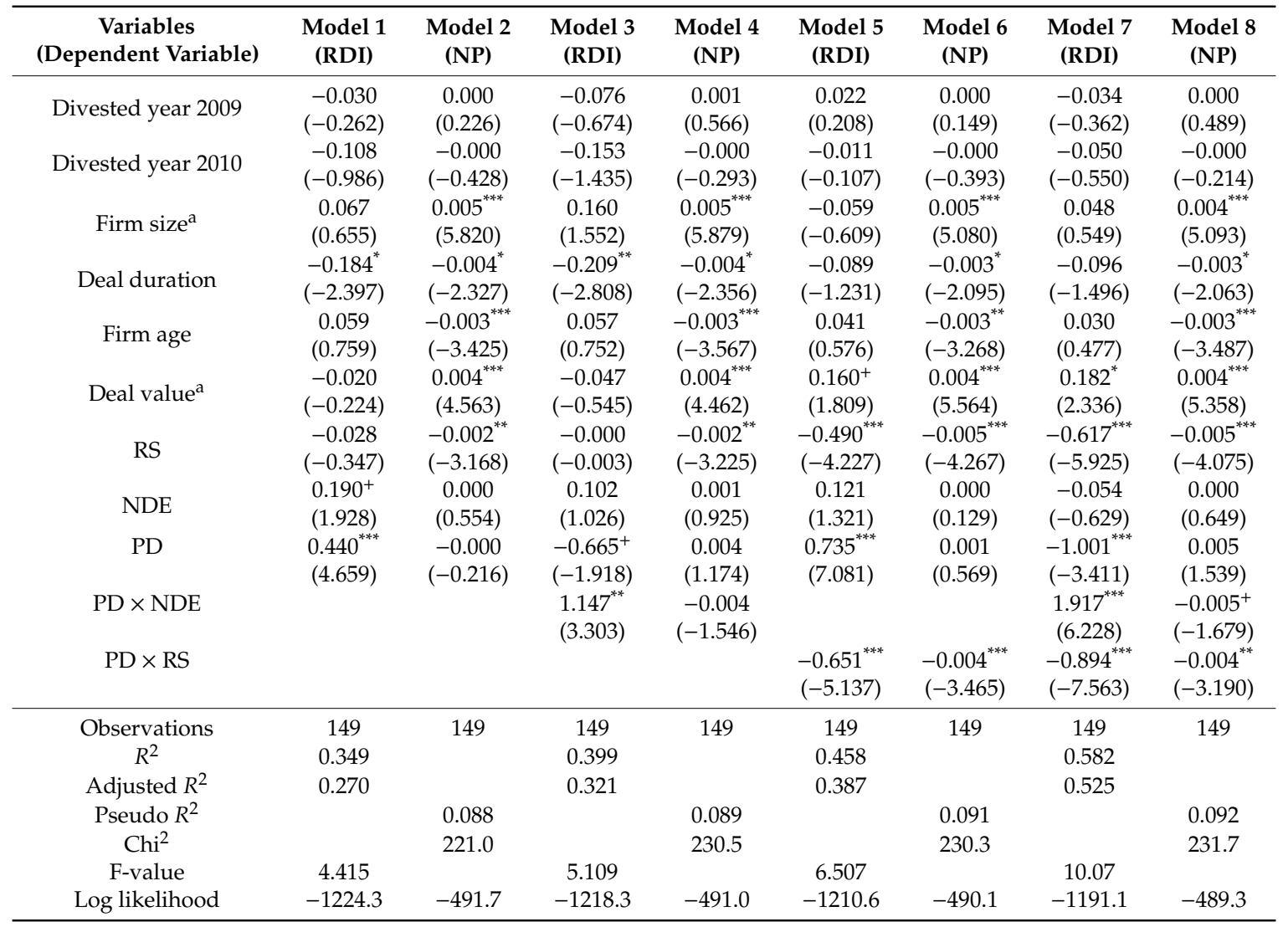

Notes: ${ }^{a}$ logarithm, RDI = R\&D intensity, NP = number of patents, RS = relative size, NDE = number of divestiture experience, $\mathrm{PD}=$ proactive divestiture. Base industry is software $\left(\mathrm{SIC}_{2 \text { digit }}=73\right)$ relative to other industries; base divested year is 2011 relative to other divested years; standardized beta coefficients; $t$ statistics in parentheses; ${ }^{+} p<0.1,{ }^{*} p<0.05,{ }^{* *} p<0.01,{ }^{* * *} p<0.001$.

In Models 1 and 2, we regressed R\&D intensity and the number of patents on all explanatory variables such as all control variables and independent variables, including RS (relative size), NE (number of divestiture experience), and PD (proactive divestiture). In Models 1 and 2, PD is positively significant with $R \& D$ intensity $\left(\beta_{\mathrm{PD}}=0.440, p<0.001\right)$, whereas it is insignificant with the number of patents. Hypothesis 1 is strongly supported, but Hypothesis 2 is not supported. In Model 3 and 4 , the moderation effect of NDE is tested, and it turns out that the interaction effect is positively significant only with $R \& D$ intensity $\left(\beta_{\mathrm{PD} \times \mathrm{NDE}}=1.147, p<0.01\right)$. Since the moderation effect of NDE on the number of patents is not supported, Hypothesis 3 is partially supported. In Models 5 and 6, we tested the moderation role of RS to PD on innovation performances, and it turns out that each interaction effect is negatively significant. For R\&D intensity, the coefficient of interaction between PD and RS is $-0.651(p<0.001)$, while, for a number of patents, it is $-0.004(p<0.001)$; therefore, Hypothesis 4 is supported. In Models 7 and 8, as full models, we regressed R\&D intensity, and a number of patents on all explanatory variables and results were consistent with our hypotheses, except for Hypothesis 2, where its significance is changed to 0.01 . We plotted all significant interaction results in Figures 1-3. 


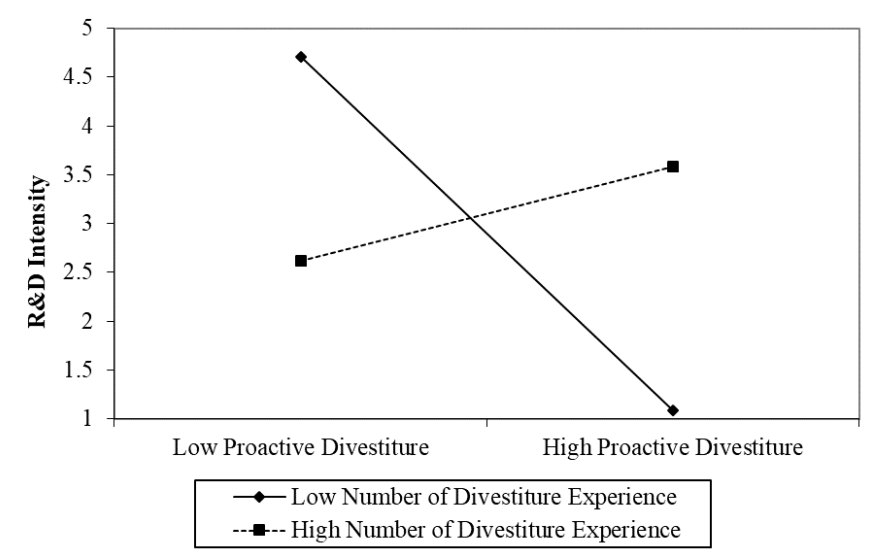

Figure 1. Interaction between proactive divestiture and the number of divestiture experiences on R\&D intensity.

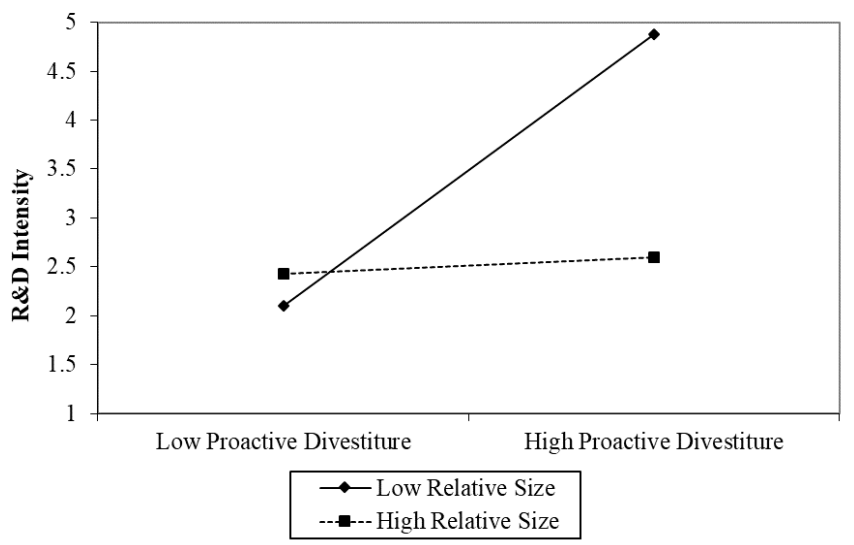

Figure 2. Interaction between proactive divestiture and relative size on R\&D intensity.

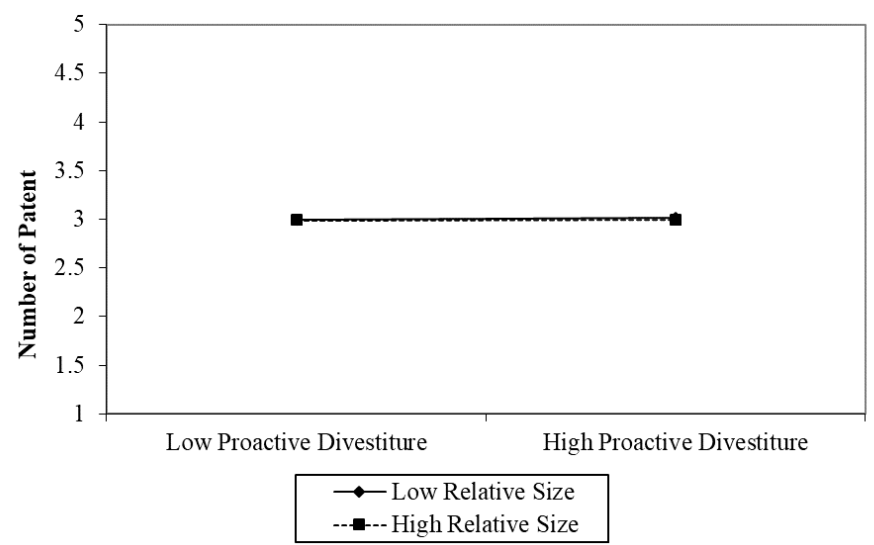

Figure 3. Interaction between proactive divestiture and relative size on the number of patents.

\section{Conclusions and Implications}

\subsection{Conclusions}

This study was conducted based on the relationship between proactive divestiture and innovation performance, which we had a particular interest and believed to have significant relevance towards corporate sustainability. The analysis of our study delivers overall support for all four hypotheses. Firms were shown to increase their R\&D intensity via a divestiture process. Therefore, Hypothesis 1, which demonstrated R\&D inputs, was supported. However, interestingly, Hypothesis 2 was not supported as the number of patents showed no relationship. Thus, we were not able to find out if firms that intensively invested in R\&D held a higher number of patents. In the case of Hypothesis 3 , 
it showed a mixed supporting result that within proactive-divestiture firms; firms with many past divestiture experiences performed better in innovation input activity but, however, not in outcome (number of patents), which we expected would also increase. Finally, Hypothesis 4 was supported for a negative relationship between the relative size of the divested unit and both R\&D intensity and several patents within proactive-divestiture firms. Thus, we were able to confirm that from a firm perspective, it would be more appealing to divest smaller units since resource commitment and effects on the remaining units would be smaller.

The findings of this research provides understanding into the relatedness between corporate divestiture and innovation performance [4,7]. Extant to existing literature, our analysis extends the insight of divestiture as a proactive action that can be implemented free of financial pressure in contrast to previous studies' assumption that divestiture is a responsive action by such distress. Notably, through our empirical study, we have revealed how proactive divestiture can support R\&D input (intensity) and thus promote higher R\&D output (number of patents). Moreover, we investigated how a number of past divestiture experiences and relative size of the divesting unit can moderate the result of innovation performance among post proactive-divestiture firms. This notion further enlightened us to incorporate knowledge-based views in order to investigate and suggest innovation performance as an active and creative activity that can be performed by proactive-divestiture firms [51,69]. Such implications are more crucial in light of high-tech industries as these companies reside in the frontline of frequent technology-driven changes that require firms to constantly reformulate their operating structure and capital assets with respect to competitors. By doing so, firms are able to increase the slack resources which could be spent on incrementing R\&D capacity and thus enhance contribution to corporate sustainability within the highly competitive environment. In addition, such action promotes firms to re-evaluate their current whereabouts and business strategies. In turn, firms are able to reform and refocus on prioritizing their core competencies and set priorities that lead to crucial capital investments required to bolster technological innovation for sustainable growth. Therefore, our results suggest that divestiture does not merely occur in response to financial distress confronted by firms. Instead, it is a proactive strategy which can be implemented not only to resolve in-house problems but also increase the knowledge-base in order to improve innovation performance and thus allow firms to achieve further growth and sustainable competitive advantage.

\subsection{Theoretical Implications}

A comprehensive review of the previous studies and an assessment of plausible inference regarding the innovative performance of judgments to divestiture demonstrate how divestiture can indeed reinforce innovative performance by firms. Mainly, we have analyzed exhaustive empirical research to illustrate how firms can benefit from discovering new opportunities for innovation and driving the establishment of the foundation for prospect development and innovation via divestiture. The results of the present research have several crucial implications for theory vis-à-vis the function of divestiture in innovation.

First, we broadened prior works by concentrating on innovative activities of parent firms and examining the purpose and consequences of divestiture decisions. Following Brauer [49] and Dranikoff et al. [12] and by previous research highlighting the significance of post-divestiture relationships between parent and divested firms, this study confirms that proactive divestiture leads firms to propel innovative input and output activities. This implies that if a business unit is divested in an appropriate period when a firm faces financial distress, it may help high-tech firms leapfrog to the next step for advanced knowledge compared with competitors. While the existing realm of M\&A studies has focused highly on value creation in terms of financial performance [69] or innovation output [7] after the buying deal, our study extends it to the selling deal between firms and the post-evaluation of innovation. These results show that proactive divestiture can be regarded as a tool for accumulation of knowledge to observe external innovation opportunities $[47,52]$ and for application to manufacturing new product development with high technology [48]. 
Second, we have incorporated a knowledge-based view to suggest innovation performance as an proactive and innovative activity which can be performed by proactive divestiture firms. Based on the resource-based view, divestiture may widen the span of study from tangible to intangible resources and can be more focused as a mechanism through which a firm improves its complementarity with synergy $[39,48,70]$ and innovative performances [7]. Our empirical findings on the relative size effect of the target business unit may hint at why divestiture per se works as a sticky resource with intangible resources. In previous studies, the central role of divestiture was a fast-cashable asset, a kind of tangible asset that is useful for a firm to exchange a business unit for a financial asset. However, in recent days, several studies have suggested that divestiture has played an essential role in sawing off unrelated resources that might hinder the complementarity among resource bundles. In this vein, we found a greater size of the target (divesting) unit as a negative effect on the positive relationship between divestiture and innovative performances. It implies that in a bigger firm, complexity may arise when a firm wants to cut off the core resource bundle from existing resources that are largely interwoven [4]. In order to develop knowledge in the long-run, it should therefore be noted that thinning out established resources is as crucial as combining resources by acquiring business units.

Third, our primary outcomes are overall coherent with studies that suggest divestitures are positively related with innovation outcome. Moreover, we have argued that divestiture is not only a mirror image of M\&As and should not be considered as merely a tool that is needed for firms to correct past mistakes or to acquire better cash flow to operate [9]. Instead, we contend that divestiture is not a product of the firm's failure, but it can result from a firm's competitive advantage. Although a traditional view regards divestiture as a reactive action, we suggest that divestiture does not develop merely from reacting to the in-house risk by firms, but it can be considered as a proactive action which can be implemented as a strategic tool free of internal threats (i.e., financial pressure). That is, since the extent to which firms face financial distress may cause them to immediately sell their business portfolio without a reconsideration of the real value, a vicious cycle of refocusing is highly likely to occur even though they get paid cash in hand by selling units. In contrast, if a firm knows the "timing to sell" through a number of selling experiences, obsession with cash-flow may be mitigated $[13,20]$. This result may be due to the fact that a greater level of proactive divestiture with prior experience can lower inertial behavior for a firm to lose the opportunity of the timing to sell and realize the value [43,44]; therefore, our finding called "when to sell" can contribute to the theory of "what to sell" in M\&A studies.

\subsection{Managerial Implications}

First, we were able to find out that prior divestiture experience and relative size of the divested unit does matter. It implies that as firms engage in more divestiture transactions and divest smaller sized business units, their innovative activity increases. It is likely that with both excess funding and increasing managerial resources to focus on internal inventions, proactive post-divestiture firms will be able to push innovative activities further. It means that firms may engage in divestiture in order to raise financial resources by trading some of its assets irrespective of financial distress. Moreover, Shin [69] asserted that successful divestiture allows firms to invest in positive-NPV projects or otherwise reallocate financial resources to exploit better opportunities. Divestiture experience is not surprising since it has been identified when firms make an organizational decision, prior practices and habitual routines perform a vital role [43]. However, such a result does not denote that firms should merely increase the number of divestment activities. This is because divestiture transactions often entail convoluted and long-winded activities that necessitate ample scrutiny by parent firms before implementation [4]. Furthermore, it requires extensive managerial discretion as managers who hold various divestiture experiences are able to well apprehend not only the advantage and disadvantage of a divestiture but also organizational procedures concerned with implementation [21]. Nonetheless, it is worth mentioning that the number of prior divestiture experiences are crucial to foster innovation performance since the marginal return of one action improves other activities simultaneously [46]. 
Thus, internal know-how could improve marginal returns to external know-how as an accumulation process continues. This would ultimately result in differences in absorptive capacity that the firm maintains from competitors since better understanding permits firms to evaluate and implement technologies that would further enhance the new technological development that is central to corporate sustainability [29]. Furthermore, we have observed that when firms divest larger units relative to the firm, they perform closed-innovation. As for the relative size of the divested unit, our results indicate that compared to raising financial resources by divesting smaller business units, the removal of larger business units could cause greater negative effects on the strategy-structure linkage [50], involvement in firm's decisions [32], and overall firm performance [5,49], and thus rather constrains firms from sustainable business operations. This is because, as the size of the divesting unit increases, the business unit itself could be more fundamentally connected via psychological and financial bonds with the parent firm [33]. Thus, complex affiliation amongst numerous divisions and individuals could generate problems among the remaining units. Since large units have a higher probability of a close relationship with the firm's core business, financial investment, and managerial effort, and their divestment would result in the discontinuity of critical supply relationships and a difficulty of replacement $[33,44]$. Consequently, this study advises managers of parent firms to take increased consideration when deciding to divest relatively larger business units.

Second, we argue that practitioners can implement divestiture to revitalize their firms only if they can observe further the stigma that is connected with divesting business units and incorporate it as a crucial strategic tool [12]. The answer to fathom the proper timing for divesting business units and developing in the period of low growth is to act proactively and determinedly to sell units that are considered healthy but hamper the development of innovation. Divestiture should not be considered as a last resort but as a useful strategic tool that can promote firms to grow and flourish in the long run. Astute managers should divest existing business units, not wait until such transactions turn out to be inevitable for firms to resolve problems but to encourage the generation of new, high-growth businesses. Excess funds, management times, and accompanying resources that are unshackled via divestiture should thus be reinvested and utilized to promote developing new products and activities. This might be considered irrational to some managers since selling an established business and going through harsh periods to start and develop new products could be considered as an unpromising gamble. However, more likely than not, such a transaction indicates financing in appealing growth opportunities that no others can foresee. Invention and destruction are inevitable since neither can thrive without including the other.

\subsection{Limitations}

This study is contingent on several limitations. First, a limited sample size poses one limitation. For firms that are not public (e.g., private), some information, such as deal values, are often not publicly available to access. Hence, the final number of datasets for observation could decrease significantly, compared to initial number of data gathered, as missing or unavailable data could exist during the data wrangling process. Information on firms being acquired or divested are especially hard to come by compared to acquiring companies, even for U.S. companies [13], and thus the lack of such data could winnow the final sample. The issue with a small sample size is that it may decrease the statistical power which could affect the probability of retaining the alternative hypothesis [71]. Nonetheless, as we extant our analysis from prior divestiture studies, previous research also suffered similar limitations caused by unavailable or missing data $[5,49,52]$. The limited reach of the dataset poses another limitation. The dataset is comprised of US-based publicly held firms within the high-tech industries. Limiting the dataset to only high-tech industries may reduce its generalizability. For different countries, distinct localization policies could affect how firms execute different types of divestiture strategies: liquidation, M\&As, sale to a third party, buy-outs, IPO, and shutdown. However, to eliminate potential confounding variables such as country risks or regulatory matters associated with M\&A transactions, this study has been limited to US-based firms. Moreover, as this paper limited the sample to high-tech industries, 
there is a possibility that firms residing in other industries could perform different divestiture strategies rather than via M\&A for different reasons [72]. However, investment in innovation is considered valuable tool and not a cost for high-tech industries as such industry resides in the frontline of frequent technology-driven changes, where they now have to confront new challenges from competitors beyond their conventional business sectors in order to achieve sustainable business operations. As this study adopted the patent as a proxy measure for the innovation outcome, we selected the industry where patents are considered most meaningful [48].

Future research could be conducted on the basis of our discussion in limitations. First, as mentioned earlier, different country and industry settings could influence how firms employ divestiture. By looking into different types of strategies within divestiture transactions, this would lead us to extend our knowledge on corporate divestiture and innovation performance. Second, studies could be conducted on different measurements to observe the meaningful relationships between proactive-divestiture and innovation performance. Although the number of patents are identified as a vital means to have an important role in demonstrating innovative performance [35], there are certain limitations. For one, there may exist a gap between R\&D inputs and outputs. Not all R\&D activities lead to patents and not all novel inventions are patented [73]. Rather than number of patents, for some firms, the number of patent citations could be an indicator of influential innovation [74]. Consequently, selecting an industry with a sufficient amount of data with various indicators of innovation performance could further enrich the context of proactive-divestiture and innovation outcome. Lastly, longitudinal studies could be a promising avenue to observe the long-term effect of such a relationship, which is essential for corporate sustainability.

Author Contributions: Conceptualization, K.L. and T.R.; methodology, K.L. and T.R.; formal analysis, K.L. and T.R.; investigation, K.L. and T.R.; data curation, K.L. and T.R.; writing - original draft preparation, K.L. and T.R.; writing-review and editing, K.L. and T.R.; supervision, T.R. All authors have read and agreed to the published version of the manuscript.

Acknowledgments: This work was an excerpt from the master thesis of Kyungsuk Lee at Seoul National University and was supported by the Soonchunhyang University Research Fund.

Conflicts of Interest: The authors declare no conflict of interest.

\section{References}

1. Berger, P.G.; Ofek, E. Diversification's effect on firm value. J. Financ. Econ. 1995, 37, 39-65. [CrossRef]

2. Szekely, F.; Strebel, H. Incremental, radical and game-changing: Strategic innovation for sustainability. Corp. Gov. 2013, 13, 467-481. [CrossRef]

3. Teece, D.J.; Pisano, G.; Shuen, A. Dynamic capabilities and strategic management. Strat. Manag. J. 1997, 18, 509-533. [CrossRef]

4. Moschieri, C.; Mair, J. Adapting for innovation: Including divestitures in the debate. Long Range Plan. 2011, 44, 4-25. [CrossRef]

5. Brauer, M.; Mammen, J.; Luger, J. Sell-offs and firm performance: A matter of experience? J. Manag. 2017, 43, 1359-1387. [CrossRef]

6. Hamilton, R.T.; Chow, Y.K. Why managers divest—evidence from New Zealand's largest companies. Strat. Manag. J. 1993, 14, 479-484. [CrossRef]

7. Peruffo, E.; Pirolo, L.; Nenni, M.E. Spin-off and innovation in the pharmaceutical industry. Int. J. Eng. Bus. Manag. 2014, 6, 1-7. [CrossRef]

8. Sarda, D.; Rimner, M. M\&A Due Diligence What Corporates Can Learn from Private Equity. Available online: https://www.legalexecutiveinstitute.com/wp-content/uploads/2018/04/315PM-Accenture-MA-DueDiligence-Corporates-Learn-Private-Equity.pdf (accessed on 13 March 2019).

9. Montgomery, C.A.; Thomas, A.R.; Kamath, R. Divestiture, market valuation, and strategy. Acad. Manag. J. 1984, 27, 830-840. [CrossRef]

10. Gibbs, P.A. Determinants of corporate restructuring: The relative importance of corporate governance, takeover threat, and free cash flow. Strat. Manag. J. 1993, 14, 51-68. [CrossRef] 
11. Chatterjee, S.; Harrison, J.S.; Bergh, D.D. Failed takeover attempts, corporate governance and refocusing. Strat. Manag. J. 2003, 24, 87-96. [CrossRef]

12. Dranikoff, L.; Koller, T.; Schneider, A. Divestiture: Strategy's missing link. Harv. Bus. Rev. 2002, 80, 74-75. [PubMed]

13. Hayward, M.L.A.; Shimizu, K. De-commitment to losing strategic action: Evidence from the divestiture of poorly performing acquisitions. Strat. Manag. J. 2006, 27, 541-557. [CrossRef]

14. Cohen, J.; Gaynor, L.M.; Krishnamoorthy, G.; Wright, A.M. Auditor communications with the audit committee and the board of directors: Policy recommendations and opportunities for future research. Account. Horiz. 2007, 21, 165-187. [CrossRef]

15. Darnall, N.; Edwards, D. Predicting the cost of environmental management system adoption: The role of capabilities, resources and ownership structure. Strat. Manag. J. 2006, 27, 301-320. [CrossRef]

16. Brunetta, F.; Peruffo, E. May parents inherit from heirs? Towards an understanding of the parent-spun-off relationship. Am. J. Appl. Sci. 2014, 11, 921-928. [CrossRef]

17. Bergh, D.D.; Lim, E.N.-K. Learning How to Restructure: Absorptive Capacity and Improvisational Views of Restructuring Actions and Performance. Strat. Manag. J. 2008, 29, 593-616. [CrossRef]

18. Markides, C.; Singh, H. Corporate restructuring: A symptom of poor governance or a solution to past managerial mistakes? Eur. Manag. J. 1997, 15, 213-219. [CrossRef]

19. Jensen, M.C. Active investors, LBOs, and the privatization of bankruptcy. J. Appl. Corp. Financ. 1989, 2, 35-44. [CrossRef]

20. Whitaker, R.B. The early stages of financial distress. J. Econ. Financ. 1999, 23, 123-132. [CrossRef]

21. Kim, Y.; Roh, T. Shackles of the past: Why firms divest too late and when they can free themselves. Acad. Manag. Annu. Meet. Proc. 2014, 1, 1292-1297. [CrossRef]

22. Graebner, M.E.; Eisenhardt, K.M. The seller's side of the story: Acquisition as courtship and governance as entrepreneurial firms. Adm. Sci. Q. 2004, 49, 366-403. [CrossRef]

23. Kogut, B.; Zander, U. Knowledge of the firm, combinative capabilities, and the replication of technology. Organ. Sci. 1992, 3, 383-397. [CrossRef]

24. Grant, R.M. Toward a knowledge-based theory of the firm. Strat. Manag. J. 1996, 17, 109-122. [CrossRef]

25. Ahuja, G.; Katila, R. Technological acquisition and the innovation performance of acquiring firms: A longitudinal study. Strat. Manag. J. 2001, 22, 197-220. [CrossRef]

26. Henderson, R.; Cockburn, I. Scale, scope, and spillovers: The determinants of research productivity in drug discovery. Rand J. Econ. 1996, 27, 32-59. [CrossRef]

27. Hoskisson, R.O.; Johnson, R.A. Corporate restructuring and strategic change: The effect on diversification strategy and R\&D intensity. Strat. Manag. J. 1992, 13, 625-634. [CrossRef]

28. Capron, L.; Mitchell, W. Selection capability: How capability gaps and internal social frictions affect internal and external strategic renewal. Organ. Sci. 2009, 20, 294-312. [CrossRef]

29. Hansen, E.G.; Grosse-Dunker, F.; Reichwald, R. Sustainability innovation cube-A framework to evaluate sustainability-oriented innovations. Int. J. Innov. Manag. 2009, 13, 683-713. [CrossRef]

30. Johnson, R.A. Antecedents and outcomes of corporate refocusing. J. Manag. 1996, 22, 439-483. [CrossRef]

31. Hannan, M.T.; Freeman, J. Structural inertia and organizational change. Am. Sociol. Rev. 1984, 49, 149-164. [CrossRef]

32. Koch, J.; Fox, C. The industrial relations setting, organizational forces, and the form and content of worker participation. Acad. Manag. Rev. 2014, 3, 572-583. [CrossRef]

33. Duhaime, I.M.; Baird, I.S. Divestment decision-making the role of business unit size. J. Manag. 1987, 13, 483-498. [CrossRef]

34. Canzano, D.; Grimaldi, M. An integrated framework to implement a knowledge management programme: The role of technological tools and techniques. Int. J. Intell. Enterp. 2012, 1, 233-247. [CrossRef]

35. Hagedoorn, J.; Cloodt, M. Measuring innovative performance: Is there an advantage in using multiple indicators? Res. Policy 2003, 32, 1365-1379. [CrossRef]

36. Beneito, P. Choosing among alternative technological strategies: An empirical analysis of formal sources of innovation. Res. Policy 2003, 32, 693-713. [CrossRef]

37. Burgelman, R.A. Strategy making as a social learning process: The case of internal corporate venturing. Interfaces 1988, 18, 74-85. [CrossRef] 
38. Capron, L. The long-term performance of horizontal acquisitions. Strat. Manag. J. 1999, 20, 987-1018. [CrossRef]

39. Harrison, J.S.; Hitt, M.A.; Hoskisson, R.E.; Ireland, R.D. Synergies and post-acquisition performance: Differences versus similarities in resource allocations. J. Manag. 1991, 17, 173-190. [CrossRef]

40. Karim, S.; Mitchell, W. Innovating through acquisition and internal development: A quarter-century of boudary evolution at Johnson \& Johnson. Long Range Plan. 2004, 37, 525-547. [CrossRef]

41. Hitt, M.A.; Hoskisson, R.E.; Ireland, R.D. Mergers and acquisitions and managerial commitment to innovation in M-form firms. Strat. Manag. J. 1990, 11, 29-47.

42. Jensen, R. Information cost and innovation adoption policies. Manag. Sci. 1988, 34, 230-239. [CrossRef]

43. Cyert, R.M.; March, J.G. A Behavioral Theory of The Firm; Prentice-Hall: Upper Saddle River, NJ, USA, 1963.

44. Shimizu, K.; Hitt, M.A. What constrains or facilitates divestitures of formerly acquired firms? The effects of organizational inertia. J. Manag. 2005, 31, 50-72. [CrossRef]

45. Amburgey, T.L.; Kelly, D.; Barnett, W.P. Resetting the Clock: The Dynamics of Organizational Change and Failure. Adm. Sci. Q. 1993, 38, 51-73. [CrossRef]

46. Cassiman, B.; Veugelers, R. In search of complementarity in innovation strategy: Internal R\&D and external knowledge acquisition. Manag. Sci. 2006, 52, 68-82. [CrossRef]

47. Cohen, W.; Levinthal, D. Absorptive capacity: A new perspective on learning and innovation. Adm. Sci. Q. 1990, 35, 128-152. [CrossRef]

48. Makri, M.; Hitt, M.A.; Lane, P.J. Complementary technologies, knowledge relatedness, and invention outcomes in high technology mergers and acquisitions. Strat. Manag. J. 2010, 31, 602-628. [CrossRef]

49. Brauer, M. What have we acquired and what should we acquire in divestiture research? A review and research agenda. J. Manag. 2006, 32, 751-785. [CrossRef]

50. Grinyer, P.H.; Yasai-Ardekani, M. Strategy, structure, size and bureaucracy. Acad. Manag. J. 1981, 24, 471-486. [CrossRef]

51. Lee, D.D.; Madhavan, R. Divestiture and firm performance: A meta-analysis. J. Manag. 2010, 36, $1345-1371$. [CrossRef]

52. Bergh, D.D.; Johnson, R.A.; Dewitt, R.L. Restructuring through spin-off or sell-off: Transforming information asymmetries into financial gain. Strat. Manag. J. 2008, 29, 133-148. [CrossRef]

53. Lovejoy, F.A. Divestment for Profit; Financial Executives Research Foundation: Morristown, NY, USA, 1971.

54. Latham, S. Contrasting strategic response to economic recession in start-up versus established software firms. J. Small Bus. Manag. 2009, 47, 180-201. [CrossRef]

55. Thornhill, S. Knowledge, innovation and firm performance in high- and low-technology regimes. J. Bus. Ventur. 2006, 21, 687-703. [CrossRef]

56. Wang, Z.; Wang, N. Knowledge sharing, innovation and firm performance. Expert Syst. Appl. 2012, 39, 8899-8908. [CrossRef]

57. Benou, G.; Madura, J.; Ngo, T. Wealth creation from high-tech divestitures. Q. Rev. Econ. Financ. 2008, 48, 505-519. [CrossRef]

58. Valentini, G. Measuring the effect of M\&A on patenting quantity and quality. Strat. Manag. J. 2012, 33, 336-346.

59. Hoskisson, R.E.; Johnson, R.A.; Moesel, D.D. Corporate divestiture intensity in restructuring firms: Effects of governance, strategy, and performance. Acad. Manag. J. 1994, 37, 1207-1251. [CrossRef]

60. Goldie, B.A. Takeovers and the size effect. Q. J. Financ. Account. 2014, 52, 53.

61. Siegel, P.A.; Hambrick, D.C. Pay disparities within top management groups: Evidence of harmful effects on performance of high-technology firms. Organ. Sci. 2005, 16, 259-274. [CrossRef]

62. Mariotti, S.; Piscitello, L. Is divestment a failure or part of a restructuring strategy? The case of Italian transnational corporations. Transnatl. Corp. 1999, 8, 25-34.

63. Gulati, R.; Lavie, D.; Singh, H. The nature of partnering experience and the gains from alliances. Strat. Manag. J. 2009, 30, 1213-1233. [CrossRef]

64. Wooldridge, J.M. Econometric Analysis of Cross Section and Panel Data; MIT Press: Cambridge, MA, USA, 2002.

65. Greene, W. Econometric Analysis, 5th ed.; Prentice Hall: Upper Saddle River, NJ, USA, 2003.

66. Nesta, L.; Saviotti, P.P. Coherence of the knowledge base and the firm's innovative performance: Evidence from the U.S. pharmaceutical industry. J. Ind. Econ. 2005, 53, 123-142. [CrossRef] 
67. Licht, G.; Zoz, K. Patents and R\&D: An econometric investigation using applications for German, European and US patents by German companies. In The Economics and Econometrics of Innovation; Encaoua, D., Hall, B.H., Laisney, F., Mairesse, J., Eds.; Springer: Boston, MA, USA, 2000; pp. 307-338.

68. Hair, J.F.; Black, W.C.; Babin, B.J.; Anderson, R.E.; Tatham, R.L. Multivariate Data Analysis; Prentice Hall: Upper Saddle River, NJ, USA, 1998.

69. Shin, G.H. The profitability of asset sales as an explanation of asset divestitures. Pac. Basin Financ. J. 2008, 16, 555-571. [CrossRef]

70. Harrison, J.S.; Hitt, M.A.; Hoskisson, R.E.; Ireland, R.D. Resource complementarity in business combinations: Extending the logic to organizational alliances. J. Manag. 2001, 27, 679-690. [CrossRef]

71. Springate, S.D. The effect of sample size and bias on the reliability of estimates of error: A comparative study of Dahlberg's formula. Eur. J. Orthod. 2012, 34, 158-163. [CrossRef]

72. DeTienne, D.R.; McKelvie, A.; Chandler, G.N. Making sense of entrepreneurial exit strategies: A typology and test. J. Bus. Ventur. 2015, 30, 255-272. [CrossRef]

73. Hitt, M.A.; Hoskisson, R.E.; Ireland, R.D.; Harrison, J.S. Effects of acquisitions on R\&D inputs and outputs. Acad. Manag. J. 1991, 34, 693-706.

74. Gambardella, A.; Harhoff, D.; Verspagen, B. The value of European patents. Eur. Manag. Rev. 2008, 5, 69-84. [CrossRef]

(C) 2020 by the authors. Licensee MDPI, Basel, Switzerland. This article is an open access article distributed under the terms and conditions of the Creative Commons Attribution (CC BY) license (http://creativecommons.org/licenses/by/4.0/). 